\title{
READING COMPREHENSION IN SOUTH AFRICAN SCHOOLS: ARE TEACHERS GETTING IT, AND GETTING IT RIGHT?
}

Elizabeth J Pretorius, University of South Africa

Nanda M Klapwijk, University of South Africa

Much research exists about South African learners' low literacy and numeracy levels and about poorly performing schools. In contrast, there are far fewer detailed descriptions of instructional practices and what teachers are actually doing in their classrooms, and far less evidence exists of in-depth research attempts to understand in what way and why teachers may experience problems with the teaching of reading literacy, particularly reading comprehension. This article aims to contribute to narrowing that gap by reviewing recent South African research on classroom comprehension instruction and obtaining information from teachers about how they perceive themselves as readers, what their teaching context is, what they claim to be doing about reading in their classrooms, and to match these responses with ANA results at their schools. Data were obtained through a quantitative questionnaire from 159 teachers at 30 schools across three provinces. The results show that many teachers are not themselves immersed in rich reading practices, many teachers claim to be doing more than is reflected in their schools' literacy results, and in general teachers don't seem to have a clear understanding of reading concepts, reading development and reading methodology.

\section{INTRODUCTION}

The widespread low performance of South African learners on literacy assessments is by now well documented, not only in systemic reports, the reports on the Annual National Assessments (ANAs), but also in international reports based on the Southern and Eastern Africa Consortium for Monitoring Educational Quality (SACMEQ), 2010) and the South African results of the Progress in International Reading (PIRLS) study of 2006 and 2011 as reported in Howie et al. $(2008,2012)$. As a result of these sobering outcomes, several measures have been put in place at national and provincial level in an attempt to turn the literacy tide. For example, 13 years after the introduction of Outcomes-based Education it was acknowledged that OBE was inappropriate and not producing the desired learning outcomes (Le Clercq, 2014). The new Curriculum Assessment Policy Statement (CAPS) was designed to provide a more structured and sequenced approach to literacy instruction, explicitly articulating pacing, time on task and learning outcomes.

In the Western Province Education Department, the Literacy and Numeracy Strategy 20062016 was put in place in reaction to "alarmingly poor literacy levels" (Western Cape Department of Education, 2006:4). In 2008 the Foundations for Learning programme was implemented countrywide by the Department of Education to improve the literacy levels of Grade 1-6 learners, outlining how literacy should be taught. There has also been the implementation of the Dutch-funded TEP PROJECT 20 (Reading literacy in schools and teacher development), and the implementation of the Gauteng Primary Literacy and 
Mathematics Strategy (GPLMS) which targeted 792 underperforming primary schools in the province. Mpumalanga province implemented the School Transformation and Reform Strategy (STARS) and KwaZulu-Natal Department of Education recently initiated the LitNum Strategy (LNS). The Department of Basic Education put a plan in place to implement Early Grade Reading Assessment (EGRA) in 100 schools per province in Grades 1-3 in 2015. The aim of this EGRA initiative is to assess foundational readings skills in the early grades so as to identify reading problems early and to adapt instructional practice to learner needs (Department of Basic Education, 2014: 21). These literacy initiatives and curriculum changes indicate that the literacy crisis is readily acknowledged and responses are being designed and implemented to improve the education system in different ways and at different levels. These initiatives are also not cheap; millions of rands have been and are being spent to improve literacy and numeracy levels in the country. Have we correctly located the weaknesses in the education system and are we starting to get it right?

Referring to education in the United States, Moats (1999: 10) argues that classroom teaching for reading instruction must be the central focus and should be considered the critical factor in preventing reading problems. This implies high levels of content knowledge about reading as well as pedagogic knowledge of how best to teach it. Given the high levels of poverty in South Africa, the need - through good practice - to prevent reading problems from arising rather than try after the fact to fix them points to the urgency of making effective classroom reading instruction a priority. In line with this thinking, many of the current interventions are aimed at improving classroom practices and providing teachers with guidelines - in some cases quite detailed scripted templates for lesson plans and time management - on how to become more effective literacy teachers. The interventions at teacher level tend to involve the what and how to of literacy instruction, but not the what and how to of changing human behaviour. Simply telling teachers what to teach in terms of reading and how to do so does not, ipso facto, turn them into good reading teachers. In terms of content knowledge, reading literacy is itself a complex cognitive-linguistic phenomenon that is embedded in social values and practice. Teachers' understanding and teaching of reading may be linked to their own reading practices. Understanding where the sticking places are in terms of content and pedagogic knowledge and the multiple factors that feed into them are useful starting points for addressing the reading comprehension challenges in our educational system.

\section{READING COMPREHENSION: ATTENDANT CONTRIBUTORY FACTORS}

There are multiple reasons for the poor levels of reading comprehension of South African learners. Besides macro level factors such as high levels of poverty, low parental literacy levels, poor governance in many schools, poorly resourced schools and poorly qualified teachers, there are also factors associated more closely with language and reading literacy that relate to poor reading comprehension. These include the role of home language (HL) and the language of learning and teaching (LoLT) in reading, the focus of instructional attention related to reading, and teacher reading perceptions and practices, their reading 'habitus'. Each of these factors is briefly examined below.

The language issue: Given that the majority of learners in South Africa do their schooling through a language that is not their home language, it is natural to posit language as a factor for poor comprehension, especially in First Additional Language (FAL) reading ${ }^{1}$. However,

\footnotetext{
${ }^{1}$ In official policy documents the term 'additional language' is used to refer to the learning and teaching of a second (or third or more) language. In South Africa, English and Afrikaans are usually the 'first' additional languages (FAL) that are taught. For many African learners English FAL is introduced as a subject in Grade 1 with an African language used as the LoLT. A transition occurs in Grade 4 when English becomes the LoLT
} 
as pointed out by Howie et al. (2008: 3), in South Africa "reading problems tend to be masked by language proficiency issues ... An associated assumption is that when learners have difficulty with using reading as a tool for learning then their comprehension problems are a product of limited language proficiency". Such reading problems are often misattributed primarily to language proficiency, the assumption being that greater language proficiency will resolve reading problems. While language proficiency and reading ability are inextricably linked, language ability and reading ability are not synonymous. As Pretorius and Machet (2004: 47-48) pointed out over a decade ago, poor literacy results cannot be solely attributed to second language instruction as teachers and learners are struggling with literacy in the African Languages as well as English. This is confirmed in the South African 2006 and 2011 Progress in International Reading Literacy Study (PIRLS) results where learners who did the comprehension tests in their African home language performed most poorly of all (Howie et al. 2008; Howie et al. 2012). In these cases, having an African language as a LoLT did not automatically make the meaning of texts in the home language accessible to learners; learners could speak but not read in their home language. If time is not spent on developing reading in and out of classrooms, learners are unlikely to reach high levels of reading ability. Alexander (2006: 2) notes that "[1]anguage medium policy and practice in and of themselves are a necessary but not sufficient explanation of poor academic performance. There are many other factors that are part of the causality. Of these, socioeconomic status, teaching method and parental involvement are probably the most important".

Focus of instructional attention: Although meaningful comprehension is the goal of reading instruction, anecdotal evidence as well as local research suggests that teachers spend far more time focusing on the mechanical skills of decoding rather than on meaning and comprehension (e.g. Pretorius \& Machet, 2004; Verbeek, 2010; Murris, 2014; Prinsloo et al., 2015). Yet, since the 1980s with Brown and Palinscar's seminal work (1984), there is a large body of research literature that has clearly shown that explicitly teaching and modelling comprehension strategies can improve the comprehension abilities of readers (e.g. McNamara, 2007). Clearly, comprehension instruction is not getting the attention it deserves in South African primary school classrooms. However, a caveat is added here: poor pedagogy and instructional focus are two separate issues. Reading instruction should develop both basic decoding skills as well as comprehension, doing both effectively. Even though many teachers may spend more time on the mechanical aspects of reading than comprehension, time spent on specific instruction does not necessarily translate into effective teaching. The very poor comprehension levels in both the HL and in English FAL, even in terms of literal understanding, suggest that teachers are not effectively developing learners' basic reading skills that support comprehension. Research into the relationship between decoding and comprehension skills in both the HL and FAL suggests that many learners struggle even to decode the texts that they read (Pretorius, 2012; Van Rooy \& Pretorius, 2013; Pretorius, 2015). So even if South African teachers are spending more instructional time on decoding rather than on comprehension, it is not being done effectively. The poor reading outcomes suggest that even basic reading skills are not being properly developed, at great cost to learners' ability to 'read to learn' and subsequent academic performance. That said, the fact remains that attention to meaning and comprehension remain neglected areas in the majority of South African classrooms. Little, if any, formal comprehension instruction occurs in

but continues being taught as a language subject, FAL, up to Grade 12, together with an African home language as a subject. 
schools (Dreyer \& Nel, 2003; Klapwijk, 2011; Zimmerman \& Smit, 2014; Zimmerman, 2014).

Teacher knowledge and orientations to reading: Teachers' perceptions of reading and their own reading practices may also be contributory factors to learners' low literacy levels. Borg (2003) refers to these as "teacher cognitions" - what teachers think, know and believe and "the relationship of these mental constructs to what teachers do in the language classroom" (Borg, 2003: 81). Teachers are pivotal in developing strong literacy skills and habits in their learners, yet to do so they themselves need to be skilled readers. Focusing attention on literacy teaching and learning in the Foundation Phase, the NEEDU report of 2013 draws attention to three areas of knowledge that pose challenges for many teachers in South Africa, namely content knowledge (knowledge about the discipline or subject being taught, e.g. knowledge of the language(s) taught and used, literacy (specifically reading and writing) and literature in the case of language teachers, etc.), pedagogic content knowledge (knowing how to teach language/reading/writing effectively) and curriculum knowing (being familiar with the details of what the curriculum specifies at each grade level, e.g. knowing the CAPS and other current national education policy documents) (NEEDU, 2013; Taylor \& Taylor, 2013). As Irvine-Niakaris and Kiely (2015) show in their research, experienced ESL language teachers' pedagogic knowledge is very closely tied to their content knowledge of language, texts and assessment. To be effective reading teachers, teachers need to know about reading and how to teach it, and they also need to be skilled readers themselves who are familiar with different genres of text.

Pretorius and Machet (2004) pointed out that in the South African context there was very little in-depth research to understand why teachers may experience problems with the teaching of reading literacy, and few descriptions of what they were doing in their classroom practices. Later studies confirmed this (Fleisch, 2008). Zimmerman (2014: 1) points out that although publications about South African learners' poor literacy performance abound, "few published studies exist that describe and explain the patterns of classroom life that lead to academic achievement or failure". This situation seems to indicate that current interventions may be based on less than solid foundational understandings of what is happening and what is needed to address the difficulties experienced by teachers and schools.

The aim of this article is to take a snapshot look at what is happening, indirectly, in classrooms, and in particular what teachers claim to be doing and what their understanding of the teaching of reading comprehension entails. The article reports on a survey that was conducted into reading practices amongst primary school teachers in three provinces in South Africa, namely Gauteng, Mpumalanga and the Western Cape. This was not intended to be a large scale survey and was done in the knowledge that questionnaires have limitations in terms of information penetration; furthermore, despite attempts to minimise them, some social desirability effects are bound to occur when teachers are aware that they and their classroom practices are under scrutiny. In order to reach as many teachers as possible across three provinces, the purpose of this study was to obtain an initial exploratory cross-sectional 'reading snapshot' from different kinds of primary schools as to how teachers perceived themselves as readers, what their teaching context was and what teachers claimed to be doing about reading in their classrooms, and to match these responses with school poverty quintiles, which are an indirect reflection of ANA results (DBE, 2014: 89). Based on these outcomes, recommendations are then made for the teaching of reading comprehension in South African schools, and avenues for further research are suggested. Before reporting on the results, a brief overview is first given of research into reading comprehension in the South African context in the past decade. 


\section{OVERVIEW OF SOUTH AFRICAN LITERATURE ON READING COMPREHENSION}

Although in the past decade there have been several findings attesting to the poor literacy (and numeracy) levels of South African school children, and although local research has identified numerous contributory variables at the macro level (e.g. socio-economic factors, poorly resourced and poorly managed schools, poorly qualified teachers) and micro level (e.g. print-poor classrooms, inadequate time on task, inadequate lesson planning and ineffective instructional practices, etc.), there has not been a great deal of research, relatively speaking, on reading comprehension per se in South African schools. The PIRLS 2006 and 2011 results provided overwhelming evidence that South African Grade 4 and 5 learners struggle with reading comprehension, but the multiple and complex reasons for why this situation pertains and why it persists still need to be fleshed out. In this section we review some South African studies on reading literacy in the past eight or so years where the focus has been more specifically on reading comprehension and reading as a meaning-making process. We first deal with studies that have explored the de facto situation in classrooms and then we move to studies involving interventions that were specifically aimed at improving reading comprehension amongst Intermediate Phase learners.

There is a paucity of fine-grained qualitative research into reading as meaning making from a teacher perspective, in terms of what teachers think about and do with literacy, how they talk about it, the sense making and valuing that goes on inside their heads, and how they teach it. The doctoral studies by Gains (2010) and Verbeek (2010) make meaningful contributions in this regard at Foundation Phase level (i.e. Grades 1-3).

Using a qualitative approach involving 27 teachers, Gains (2010) firstly explores the links between teachers' early experiences of literacy and their current conceptualisations of literacy. She then goes on to investigate, in four Grade 1 classrooms, the way that these conceptualisations affect what teachers do in the classroom and how they do it. Similar to other studies, the researcher concludes that literacy in South African state schools is generally not well taught, but the study contributes a textured perspective into why this is so. A key finding points to links between the early literacy experiences of teachers, their conceptualisations of literacy and their consequent practices. The study also finds that teachers on the whole find it difficult to articulate their literacy pedagogy within a theoretical framework, there is a limited understanding of the nature and development of early literacy, there is very little evidence of perceptions of reading as a pleasurable activity and instilling a love of reading in young children, there is a lack of expressive or imaginative writing in classrooms, and an absence of specialised training in teaching English as an additional language.

Also using qualitative methods, Verbeek (2010) examined early-reading instruction in three Grade 1 classrooms in a typical mainstream township school in KwaZulu-Natal. Data collection and analysis were triangulated, based on a transect walk through classrooms, classroom observations, teacher interviews and focus group, questionnaires, and examination of classroom artefacts and learners' drawings over a six-month period. The main findings were that in the three observed classrooms, early-reading instruction is narrowly construed as primarily a code-based activity and thus practiced as such, with very little attention paid to reading as a meaningful activity. The Grade 1 learners had very little access to books or extended pieces of text, to reading as a meaning-making process or to differentiated instruction. Verbeek (2010) attributes these particular pedagogical practices to a combination 
of limiting personal reading experiences and outdated and inadequate teacher-training programmes for Foundation Phase teachers.

Nel (2011) approaches the problem from a pre-service teacher-training perspective, and examines what Foundation Phase teachers know about comprehension and how well they are trained to assess it. Using a qualitative approach, the study included lecturers who taught the B Ed course, $12 \mathrm{~B}$ Ed students in their final year and five5 Tswana home language Foundation Phase teachers. The results revealed that teacher trainees "have limited knowledge and skills with regard to basic principles relevant to reading comprehension assessment" and literal comprehension questions were used predominantly (Nel, 2011: 50). In addition, the teacher trainees lacked the knowledge and skills to administer different reading comprehension assessment tools, they did not know how to use assessment data to inform their teaching, or how to communicate effectively with parents concerning their children's reading progress. The study concludes that current pre-service teacher-training courses do not adequately prepare teacher trainees with the necessary knowledge and skills to teach and assess reading comprehension (cf. Discussion and Recommendations below).

Also working at pre-service level, Rimensberger (2014) studied the reading attitudes and habits of 171 Foundation Phase teacher trainees. She found a contradiction between their positive attitudes to reading and their acknowledgement of the importance of reading on the one hand, and their actual reading habits on the other hand. Although they claimed that reading was important, they seemed to do little of it. Most of their reading was limited to shorter texts such as magazines or social media texts, many claimed not to have time to read, and did not show familiarity with authors and books; only $16 \%$ emerged as passionate, engaged readers who gave names of authors and books that they had recently read, Rimensberger (2014: 6) suggests that teacher trainees are unlikely to become effective teachers of reading if they themselves lack "an intrinsic motivation to read".

Moving away from pre-service training to classroom realities, we encounter similar findings pointing to few personal reading habits and poor understandings of reading in general. Pretorius and Knoetze (2012) report on how a book club for teachers was used to help build teacher literacy capacity in a disadvantaged primary school. The teachers did little reading in their personal lives and were unfamiliar with the genre of children's literature. Initially they all showed a positive attitude to reading and claimed that it was important in the learning context, yet there was a disjunct between their ready affirmation of the importance of reading on the one hand and the amount of time spent on reading in the classroom and the actual reading levels of their learners on the other. The teachers' positive attitudes to reading did not translate into pedagogic action in the classrooms. To put it colloquially, they 'talked the talk' but they did not 'walk the walk'.

Mudzielwana, Joubert, Phatudi and Hartell (2012) report on the practices of Foundation Phase teachers when teaching reading comprehension to Grade 3 Venda-speaking learners. Using individual interviews, focus group interviews and classroom observations, they identified several factors leading to the learners' low reading performance. Observations showed that while teachers expected learners to perform comprehension tasks such as summarise or retell what they had read, or answer literal, interpretive or evaluative questions, there was no explicit instruction on how to do so. They reported that the teachers also seemed not to understand what reading comprehension strategies were. Teachers tended to read texts aloud in class without explaining meaning or showing how to apply strategies before, during or after reading. The teachers also complained that there were insufficient resources in Venda 
to support reading or to help teachers teach reading in Venda. Furthermore, although they had attended workshops on reading, they did not "experience a positive outcome' (Mudzielwana et al., 2012: 80). The researchers noted that although the teachers seemed to recognise the importance of reading and the need for children to interact meaningfully with texts, the classroom observations showed little commitment to the teaching of reading comprehension (2012: 81). The authors conclude that the teachers seemed to have a poor theoretical knowledge of reading and need to be given more guidelines and practical support.

In a secondary analysis of the PIRLS 2006 data from South Africa, Zimmerman and Smit (2014) present findings derived from teacher interviews, Grade 4 workbook analyses and Grade 4 classroom observations across six case study schools. Three of the schools were high performing schools (with international benchmarks ranging from 400-550) while the remaining three were low performing schools (with SA benchmarks ranging from 175-399). The teacher interviews revealed differences in teacher goals for reading, with the teachers at the higher performing schools showing a deeper understanding of reading comprehension and articulating the need to teach their learners specific strategies, while the teachers at the low performing schools seemed to view reading as mainly information retrieval. The amount and quality of the work in the workbooks also differed markedly across the schools, with the high performing schools producing more written output and covering more comprehension activities across a range of question types, and the opposite happening in the low performing schools. Classroom observations also showed that in the latter schools comprehension tended to be oral, with teachers asking mainly literal questions, while in the higher performing schools the focus was on written comprehension, involving higher-order thinking skills and engaging a variety of reading strategies. The authors conclude that given the overall low reading performance of the South African Grade 4 learners who participated in PIRLS 2006, "teachers in the majority of schools may not understand how to develop learners' reading comprehension and may not even understand that comprehension involves much more than just information retrieval" (Zimmerman \& Smit, 2014: 6).

Critical of approaches to reading that are code oriented, Murris (2014) calls for more attention to be paid to explicit comprehension instruction in South African schools from an early age. In particular, she advocates an approach called 'Philosophy with Children' (P4C) which aims to develop thinking and reasoning skills through reading comprehension. However, the details of the approach are not elaborated in the article.

We turn now to studies involving actual reading comprehension interventions. In their article Pretorius and Lephalala (2011) review a reading comprehension programme aimed at Grade 6 learners and teachers and implemented in different ways in two high poverty primary schools where reading levels were very low in both the home language, Northern Sotho, and in English, the language of learning and teaching. In one school the intervention was implemented during formal school hours, while at the second school it was offered after school as a voluntary activity. Although the intervention went through different permutations (e.g. whole class to small groups), the key elements of the intervention remained the same, namely, helping learners to identify the main elements of a story; using a few reading strategies; asking "I wonder ..." questions to engage attention and make text connections, and encouraging learners to re-read sections of text to clarify understanding. No significant improvements occurred at the school where the programme was voluntary, while a strong effect size $(d=.60)$ for English comprehension occurred at the school where the programme was implemented during a formal period, but there was no transfer effect to Northern Sotho. The stronger readers (those at the $75^{\text {th }}$ percentile) responded best to the programme, while learners with poor decoding skills (poor phonemic awareness, poor word recognition and 
slow oral reading fluency) showed very little overall improvement in comprehension. The authors conclude that when learners do not have strong decoding skills it is difficult for them to apply and integrate comprehension strategies and knowledge when they read.

Van Staden (2011) reports on a pilot study in Free State Province that included a sample of 288 Grade 4, 5 and 6 learners in a reading intervention, half of which served as the control group. The intervention included a variety of instructional strategies aimed at improving overall reading ability. These included building vocabulary, developing sight words, word recognition and spelling, making use of contextual clues while reading, and developing learners' ability to predict, infer, question, summarise and retell stories while reading in English. The learners in the intervention groups outperformed those in the control groups on all five measures and moderate effect sizes obtained for the different reading skills tested.

In her study, Klapwijk $(2011,2015 a)$ applied specific strategies taught to teachers in a Before, During and After reading framework. Teachers implemented their strategy instruction over a 15 week period and learners were tested before and after to assess outcomes. She also used a strategy transfer test to determine to what extent strategies were being implemented. The results showed that learners in the intervention group outperformed learners in the control group in terms of questioning (medium effect size), summarisation (large effect size) and monitoring (very large effect size). Klapwijk (2015b) followed up her 2011 study by applying the framework to two groups of university student teachers as part of their English course over a period of 12 weeks. Before starting the course, she gave the students a questionnaire which required them to rate their own use of reading strategies. She found that student teachers (much like the teachers reported later on in this article) rated themselves as efficient users of all the listed strategies. However, once they were formally introduced to these strategies during the course, they realised that their reported use and understanding of the strategies differed extensively from what the strategies really entailed.

It is clear from the brief review above from a handful of studies that while teachers in high performing schools in South Africa generally seem to pay attention to meaning and comprehension, teachers in lower performing schools do so to a far lesser extent. Teachers in the latter schools tend to have narrow conceptions of reading, are unfamiliar with the genre of children's literature and struggle to provide learners with the necessary guidance and support to engage with texts and develop comprehension abilities beyond literal readings of texts.

We now turn to the current study, where the main aim, through a questionnaire survey, was to establish what teachers claim to be doing in their classrooms with regard to reading comprehension, in relation to their own reading attitudes and practices. Because not all the ANA results from each school could be obtained at the time of data analysis, the schools are organised according to state/private schools and within state schools, according to quintiles (as explained further below).

\section{RESEARCH DESIGN AND METHOD}

The research involved a cross-sectional survey. Data were collected by means of a questionnaire that was administered to primary school teachers of all grades, at 30 schools in three provinces, viz. Gauteng, the Western Cape and Mpumalanga. The majority of teachers were Intermediate Phase teachers (i.e. Grades 4-6).

Given the historical disparities in schooling in the past, in an effort to level the educational playing fields, state schools in South Africa are allocated funding in terms of socio-economic measures, resulting in five5 school quintiles. Schools with lower quintiles receive the most 
subsidy per child while schools in the higher quintiles receive the least. Quintile 1 schools serve the poorest communities and thus receive the most state support. Since quintile rankings reflect socio-economic status (SES), and since SES tends to be an index of school effectiveness and literacy accomplishment (Taylor, van der Berg \& Mabogoane 2013: 5), higher quintile schools tend to be more effective schools and higher performing schools than lower quintile schools, in both literacy and numeracy outcomes (DBE, 2014: 89-91).

Because SES factors have been found to play such a pervasive role in school performance in South Africa, the responses to the questionnaire were disaggregated in terms of the school quintile ranking of the teachers that responded to the questionnaire. Two quintile groupings were used, viz. Quintiles 1-3 and Quintiles 4-5. The majority of participants from the latter group were from Quintile 5 schools (also referred to as suburban schools because they tend to be situated in leafy middle class suburbs). Teachers from private schools who participated in the survey are at schools that do not receive state funding so they were categorised separately. Schools that cater for the special needs of learners have also been identified separately as such. The four groups of schools are thus as follows: private schools, Quintile 1-3 schools; Quintile 4-5 schools and special schools.

Ethical approval for distribution of the survey questionnaire amongst teachers was obtained from the provincial education departments. Participation in the survey was voluntary and all teachers completed and signed an ethical approval form where details of the study were explained to them and their voluntary withdrawal from participation made clear.

\section{QUESTIONNAIRE}

The questionnaire comprised 40 items. Besides biographical information and information about teaching qualifications and experience, the items tapped into teachers' assessment of their learners' reading levels, how reading was taught at their schools, what strategies they taught, their learners' access to print-based materials, and the teachers' own perceptions of themselves as readers.

A mixed format was used, with some questions using a Likert scale (e.g. Often, Sometimes, Almost never) and some items presenting fixed options. Of the 164 questionnaires received, 5 were omitted from analysis due to incomplete information. Data were captured and analysed using SPSS Version 22.

\section{PARTICIPANTS}

In all, 159 teachers responded to the entire questionnaire from three different provinces. Biographical information included years of teaching rather than the age of the teachers. Years of teaching experience ranged from 1 year to 44 years. Of the sample, $25.2 \%$ of the teachers were 'young', having taught for 5 years or less; $20.1 \%$ had taught for $6-10$ years; $22.6 \%$ had taught for 11-20 years, while the majority of the teachers, $28.3 \%$, had taught for 21 or more years. This seems in line with the national trend amongst teachers in general (cf. CDE report March 2015).

In terms of teacher qualification, across the schools most teachers had diplomas $(43.5 \%)$, while $39.7 \%$ had degrees and $12 \%$ had postgraduate qualifications. In total $5.2 \%$ of the respondents had a matric qualification only. Quintile 4-5 suburban schools had the most teachers with degrees $(51 \%)$, while private schools had more teachers with postgraduate (PG) degrees. 


\section{Figure 1: Teacher qualification}

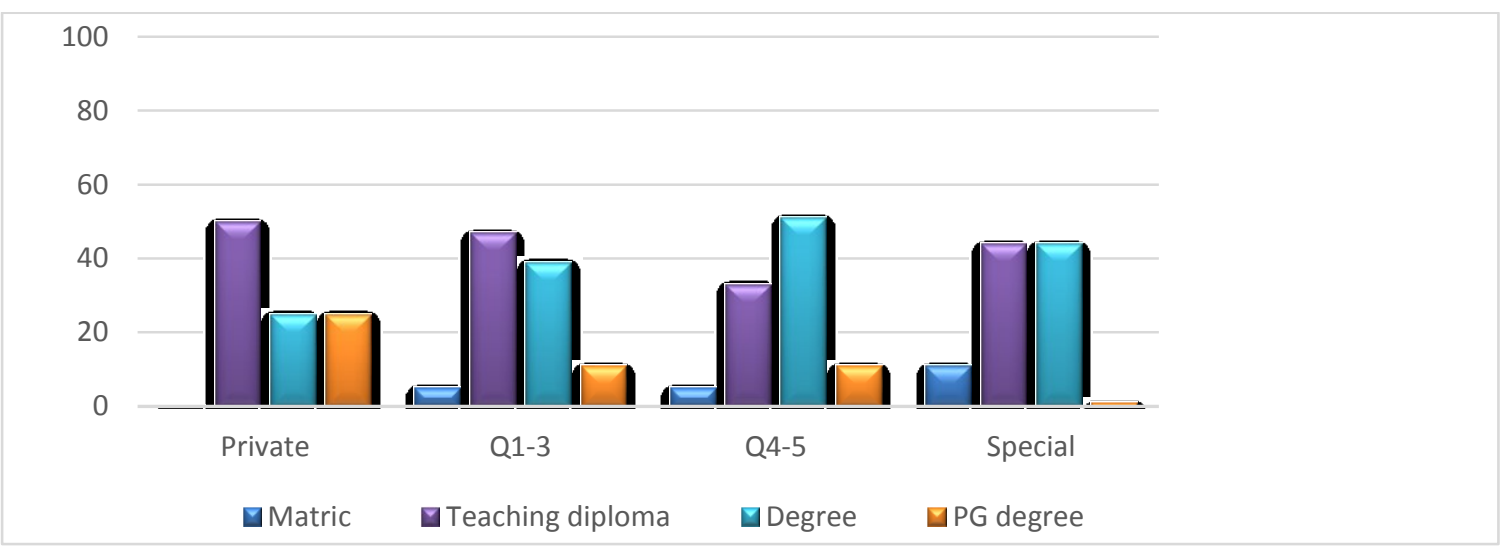

Of the 159 school teachers who responded, males are clearly underrepresented in primary schools, with only $12.7 \%$ men in the sample as opposed to $87.3 \%$ women. It was interesting to note that while $11 \%$ of the respondents in state schools were men, there were more men respondents in private schools compared to state schools (29\% versus $11 \%)$, while $89 \%$ of respondents in state schools were women as opposed to $71 \%$ women in private schools.

\section{OUTCOMES}

We first look at the teachers' perceptions of themselves as readers and their own reading habitus. Teachers from Quintile 1-3 schools reported reading less than teachers at the other schools, as reflected in Table 1. With regard to teachers' perceptions of themselves as readers, the breakdown across schools is shown in Figure 2. The majority of teachers reported enjoying reading "a lot", and rated themselves as "fast, skilled readers". While this result is entirely possible, it highlights the limitations of using a questionnaire, because teachers' interpretation of what defines a "fast, skilled reader" may well differ from what research says. A teacher in a Quintile 1 school might be from a community where the majority of adults (parents) do little to no reading, and therefore, by comparison, the teacher may regard herself as a "fast, skilled reader". The fact that teachers rated themselves as skilled readers does seem to point to the fact that they have positive attitudes towards reading in general. However, the teachers from the lower quintile schools did not seem to enjoy reading as much as teachers from the other school groups.

\section{Figure 2: Reading enjoyment}

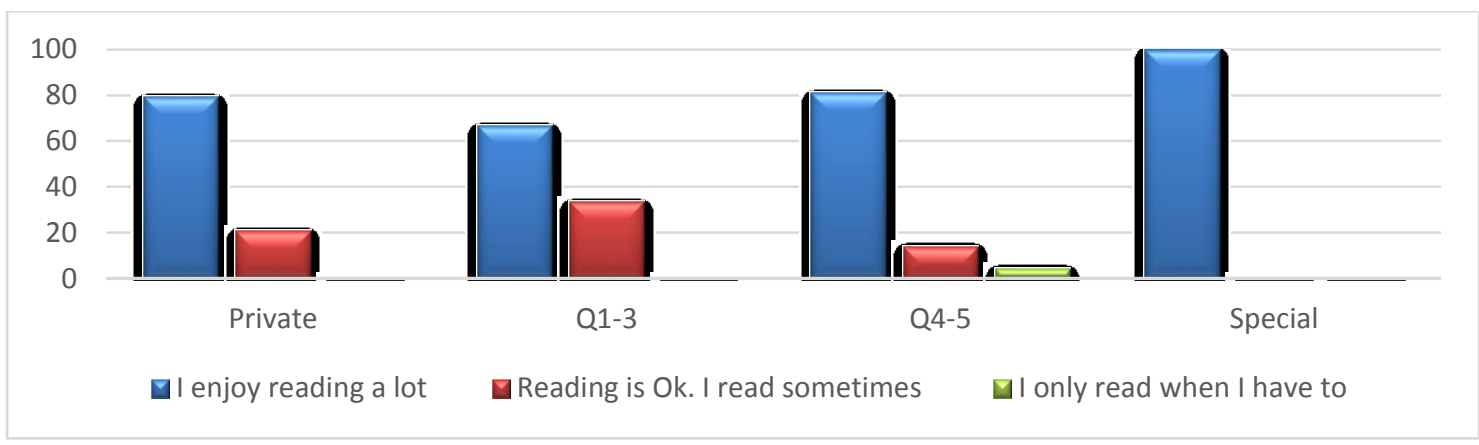

It is intriguing to note how $100 \%$ of the Special School teachers reported high reading enjoyment and yet modestly regarded themselves as average readers. Teachers who teach in these schools tend to have training in learner support ('remedial' teaching) and are more familiar than most mainstream teachers with different kinds of psychometric assessments for 
literacy and the administration of such tests. Whether their familiarity with such tests and the different processes in reading that can pose challenges for learners makes them more sensitive to reading self assessment is an interesting subject that could be pursued further.

\section{Figure 3: Self-assessment of personal reading skill}

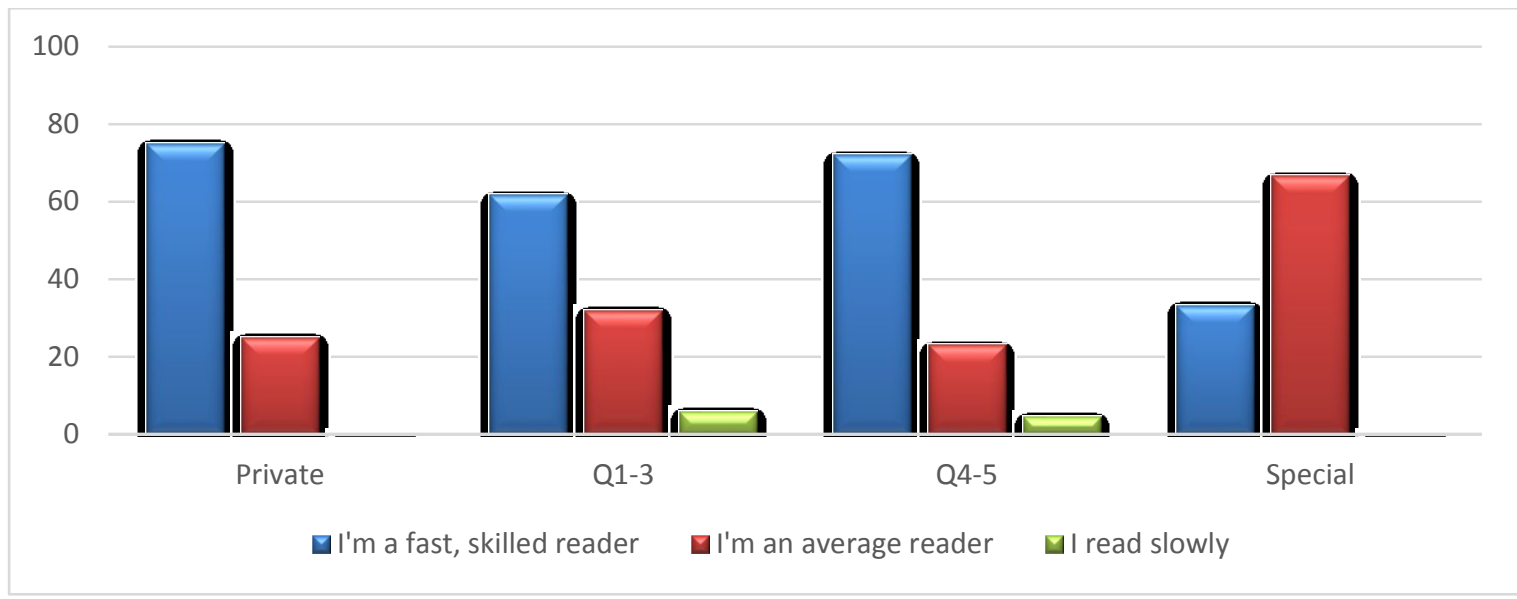

The teachers were also asked to indicate how many books they estimated to have in their home, as reflected in Figure 4. While this is admittedly a rough measure, it does reflect embedded literacy practices within the home and the value attached to books as intellectual capital. Ownership of books is clearly related to SE factors, as reflected in the differences between teachers in the poorer Quintile 1-3 schools and those in Quintile 4-5 schools. Teachers in private and special schools owned the most books. In these cases, orientation to literacy in general and the academic or pedagogic demands and expectations of their schools may also stimulate a propensity to read more widely and to purchase books as part of their professional growth.

\section{Figure 4: Books in the home}

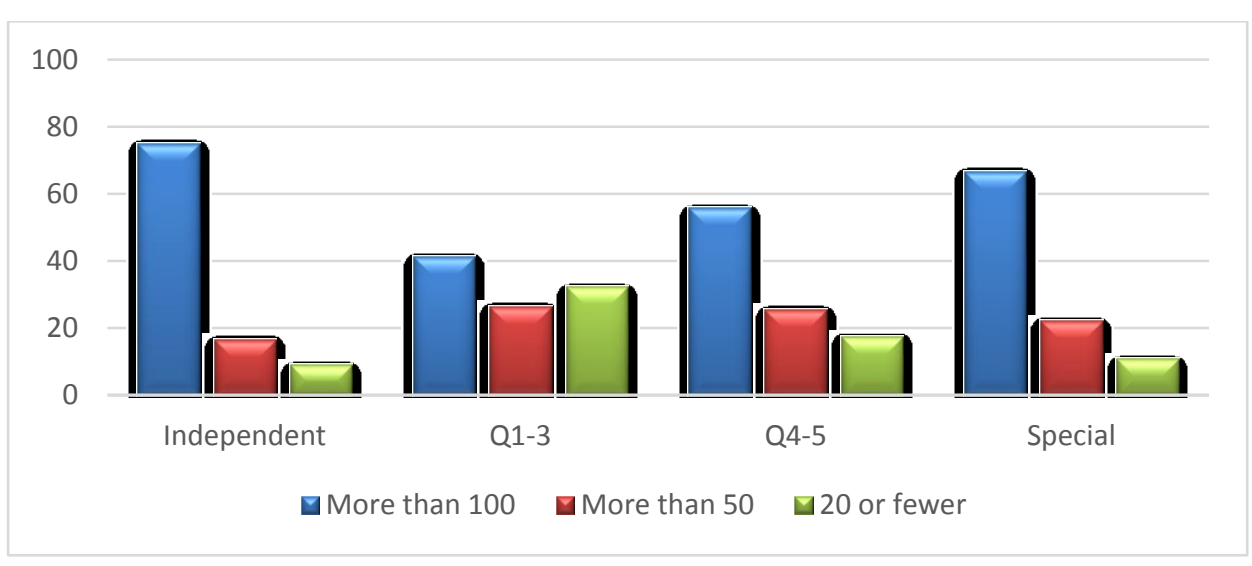

We turn now to teachers' views of their learners' reading abilities and to reading instructional issues. The questionnaire revealed a rather pessimistic view of teachers' perceptions of their learners' reading abilities. As shown in Figure 5, most teachers in state schools readily acknowledged that their learners had some or other reading problem. 
Figure 5: Teachers' perceptions of their learners' reading abilities

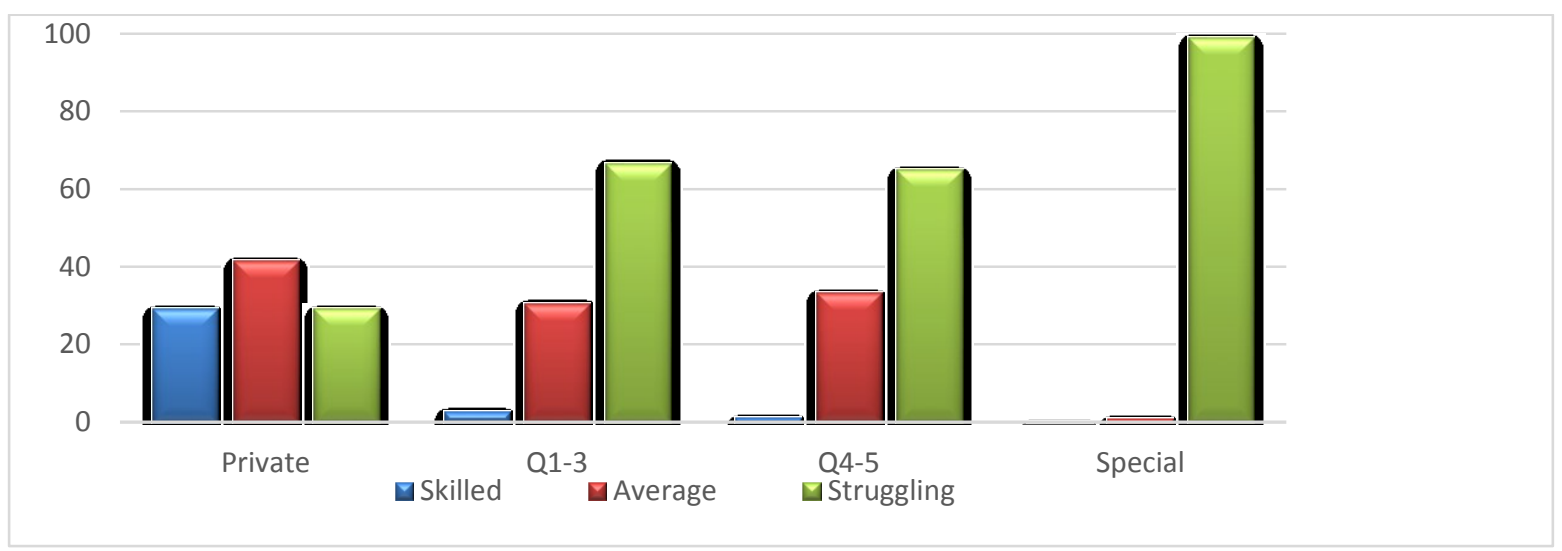

As can be seen from Figure 5, learners perceived by their teachers to be skilled readers (just under $30 \%$ ) came from private schools. Teachers in private schools also seemed to have the lowest number of readers who struggle (29\%). In contrast, very few teachers in state schools viewed their learners as being skilled readers; teachers from both township and suburban schools tended to view about one third of their learners as being average readers and more than two thirds as being readers who struggle (i.e. slow readers and/or poor comprehenders). Not surprisingly, teachers in special schools had no skilled readers and they viewed $99 \%$ of their learners as readers who struggle, ranging from moderate to severe reading problems.

With regard to reading instructional frequency, teachers were asked to indicate how often they did reading in class, as reflected in Table 5. Spending time on reading every day seems to happen most often in suburban Quintile 4-5 schools, followed by special schools. Surprisingly, even though private schools seemed to claim the most skilled readers, only $26 \%$ of teachers in private schools claimed to teach reading every day. This could indicate that their reported positive learner reading skills are due to more frequent literacy events and exposure to reading in learners' homes. Reading every day in township schools also happened less frequently (36\%). The fact that reading seems not to happen every day at many schools could also be due to timetable differences and the way in which teaching time and subjects are chunked through the week. Even so, given the poor literacy levels in the country, and given that the teachers viewed most of their learners as having reading problems, it is surprising that reading is not a daily feature in classrooms.

\section{Figure 6: Time spent on reading in class}

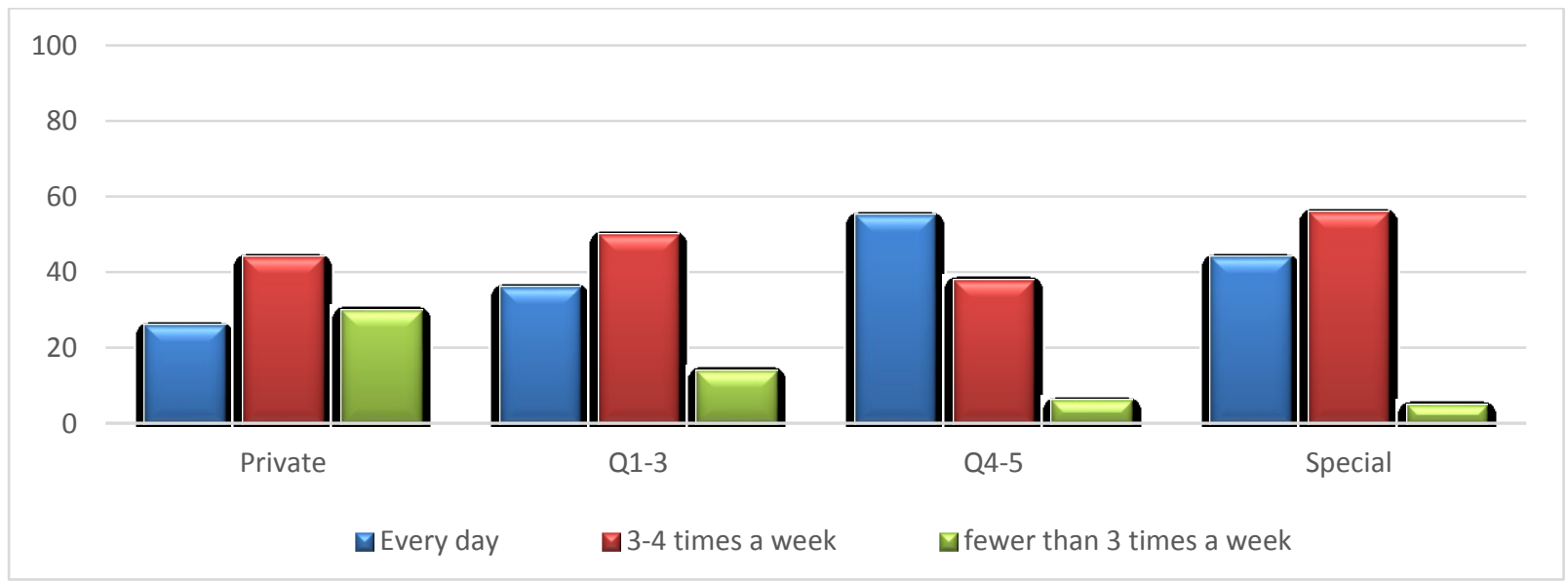


In the questionnaire teachers were asked to indicate which of eight listed strategies they taught explicitly, and whether they taught them 'often' or 'sometimes'. Figure 7 reflects eight8 comprehension strategies that teachers reported to teach explicitly the most often. Across all the schools, teaching main ideas, predicting and vocabulary were the most common. Teachers in Q1-3 also claimed to teach summary skills and how to monitor understanding while reading. In fact, the teachers in the Q1-3 claimed to teach the most strategies the most often, yet they came from low performing schools. From questionnaire responses it is difficult to establish whether teachers actually do teach these strategies explicitly or whether they are reporting on what they focus on while doing reading with their learners. For example, teachers tend to ask Do you all understand what we have read? after reading a text in class; this is indeed a form of monitoring understanding, albeit at very superficial level, but teachers could well regard it as "using the strategy of Monitoring Understanding". Similarly, identifying the text type is a strategy that requires in-depth knowledge of all genres for fiction and non-fiction texts; the research referred to in the introduction to this article seems to suggest that teachers tend to stick to a small range of text types, and mostly use fiction in their reading classes, and the related skills (questioning, summarisation) are the most commonly known ones and perceived to be easier to teach.

\section{Figure 7: Strategies reported to be taught most often}

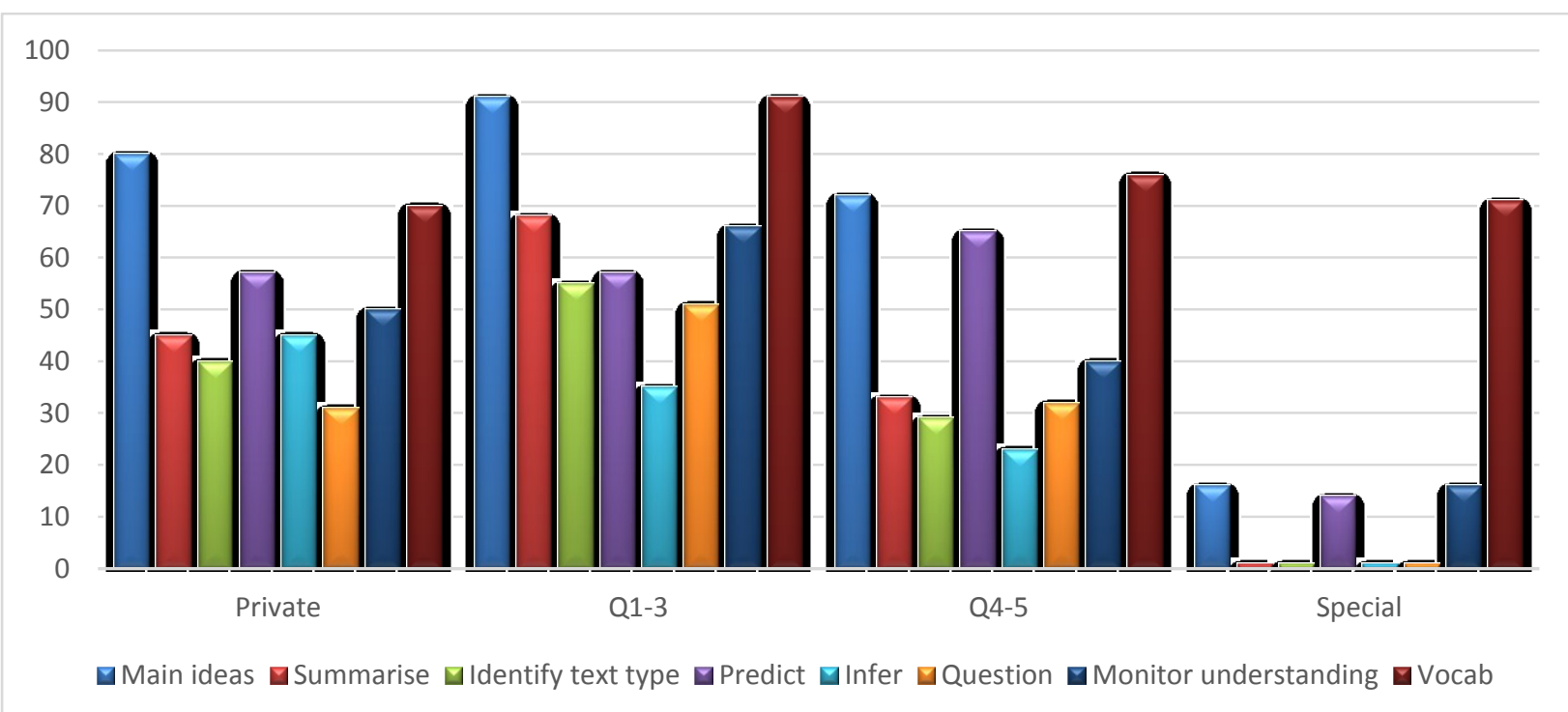

It is interesting to note the high reported instances of vocabulary teaching. Given the robust link between vocabulary and reading comprehension this is encouraging, yet how effectively it is developed and assessed throughout the year cannot be determined from a questionnaire alone. CAPS now explicitly states the vocabulary sizes that learners are expected to reach at each grade level, yet many teachers are unsure how to go about achieving these goals in a systematic manner.

Inferencing does not seem to be given explicit attention in the classroom, and this trend seems to be borne out by the PIRLS results, where learners coped better with literal questions and struggled to answer questions that involved inferring information from text information or reading between the lines. Inferencing is integral to meaning construction in text comprehension yet learners do not seem to be getting much instructional support in this area.

There appears to be a discrepancy between what the teachers claim to do and the ANA results at the schools. If the teachers were in fact teaching all these strategies explicitly and often, 
then one would expect much higher reading levels amongst learners and hence higher ANA results. What is interesting to note is that teachers at special schools do not seem to be spending much time on the explicit teaching of higher-order comprehension strategies. This may be due to the reading challenges at the decoding level that their learners face.

On being asked what they did most often after reading a text in class, the three most common activities emerged as follows:

\section{Figure 8: Common post-reading activities}

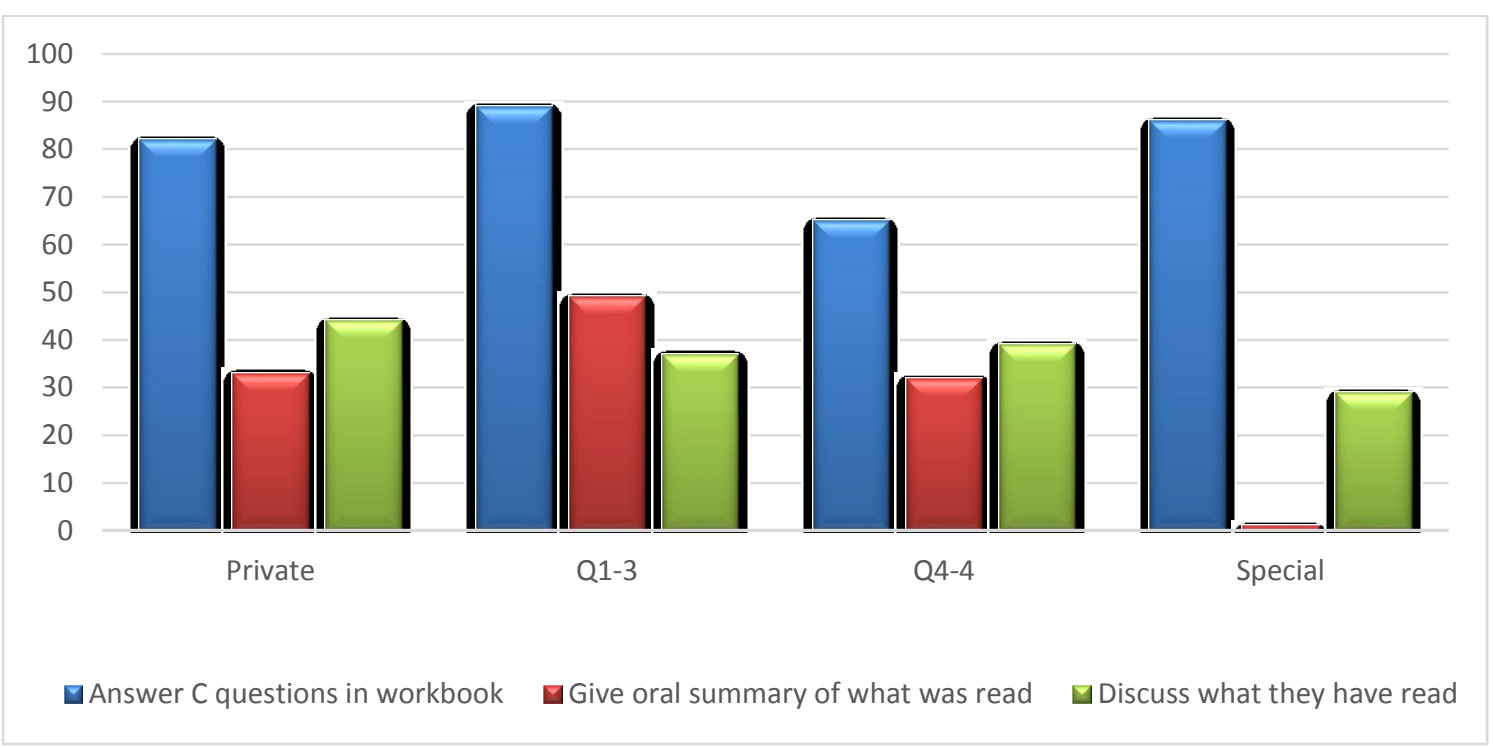

It is clear that writing answers in workbooks in response to comprehension questions is the most favoured activity, while discussing what has been read occurs less often. South African classroom research has consistently shown a lack of writing activities undertaken in low performing schools (Howie et al., 2008; Zimmerman \& Smit, 2014; Pretorius, 2015). The recent introduction by the Department of Basic Education of colourful workbooks at all grade levels in all languages may account for the high incidence now of comprehension activities in workbooks, especially in Quintile 1-3 schools. Although workbook activities are criticised for being of a mechanistic nature and not nurturing creativity (e.g. Murris, 2014), it is far better for learners in high poverty contexts to at least have workbook-based writing activities occurring in their classrooms than little to no writing opportunities at all. However, what is disquieting is the lower incidence of discussion occurring in classrooms across the school groups. As Snow (2014) forcefully argues, quality discussion in classrooms has consistently been shown to play a role in developing thinking skills, higher-order comprehension and vocabulary, especially for children from lower socio-economic backgrounds.

\section{DISCUSSION AND RECOMMENDATIONS}

Survey questionnaires are not designed to probe deeply into a subject; instead they are intended to gather information in a broad sweep in order to identify trends across the different responses. This survey looked at classroom practices in primary schools across three provinces in South Africa with regard to reading comprehension, in relation to teachers' literacy habitus and their perceptions of their own and their learners' reading skills. 
The findings from this survey suggest that the types of school where the teachers are based tend to index the extent to which teachers themselves engage in literacy practices outside the classroom and how they perceive themselves as readers. Teachers in lower performing schools (Quintiles 1-3) seem to do less reading and own fewer books than teachers in the higher performing and more affluent schools. Across all state schools, teachers readily acknowledge that their learners struggle with reading, yet surprisingly reading does not seem to be a core instructional feature in classrooms on an everyday basis.

As stated in the International Reading Association's (2007: 1) synthesis on their research into teacher preparation for reading instruction "putting a quality teacher in every classroom is key to addressing the challenges of reading achievement in schools. Knowledgeable, strategic, adaptive, and reflective teachers make a difference in student learning". In our own context Hill (2003) supports this by stating that resources must be deployed to develop a teaching corps capable of exercising judgement and taking decisive and appropriate action, but warns that effective teachers do not come cheap: the quality of their delivery will depend on the quality of their own education. Producing knowledgeable teachers is precisely the challenge in South Africa, specifically being knowledgeable about reading literacy. This implies building up literacy content knowledge as well as literacy pedagogic content knowledge, namely, how to teach reading effectively and meaningfully. Taylor (2014) argues that as a step towards greater teacher professionalism, universities tasked with pre-service teacher education arrive at some consensus on best practice in literacy and numeracy instruction. His is not an argument for uniformity in teaching but rather a quest for "broad convergence on a limited number of minimum sets of practice protocols and how to understand them theoretically" (2014: 12). Moats (1999) argues that the knowledge base for teaching reading is "hidden, extensive and complex" and should be informed by rigorous scientific evidence rather than faddish practices that prove untenable in complex classroom realities.

Van Staden and Howie (2010) state that there is a "need for Intermediate Phase teachers' continuous professional development, as Grade 4 learners' low overall achievement scores, in relation to teacher qualifications, perhaps suggests that these teachers have not been adequately prepared to teach reading literacy". The results from this study point to the fact that although teachers claim to be 'doing the right things' in their classrooms in terms of reading instruction, their schools' literacy results claim otherwise, namely that teachers' understanding of the methodologies and concepts required for effective reading instruction do not match what is required. In other words, at a deeper level they are not yet 'getting it' or 'getting it right'.

Also related to this is the finding from the current study that effective literacy instruction is linked to teachers' own reading habitus. If teachers need to develop strong literacy skills and habits in their learners, they themselves need to be skilled readers and be knowledgeable about reading and books. In the United Kingdom it was found that teachers' knowledge of children's literature increased the reading habits of children: "if you don't have teachers who are readers then their impact on the children's reading is not as effective. Teachers have got to like reading themselves to be able to transfer the enthusiasm" (O'Sullivan \& McGonigle, 2010: 52). Professional norms and standards may have been too lax in this regard in the past. If reading is central to academic performance in schooling, then at the very least, teachers who teach reading must themselves be skilled readers who have developed a professional reading habitus. 
Referring to the American context, Sailors (2008: 653) claims that "teachers are taught basic skills of reading instruction and sent out to teach with the understanding that, in time, they will learn all that they need to know to support comprehension. This is simply not true." The same can be said of the South African context, on two counts. Firstly, are pre-service and inservice teachers even taught basic skills of reading instruction and the underlying conceptual basis that informs such instruction? Taylor (2014) points out that literacy development and instruction constitute about $6 \%$ in teacher development courses across the country. Given the literacy crisis in the country, this miniscule attention to literacy in tertiary level curricula cannot remotely begin to develop teacher trainees into teachers who are knowledgeable about literacy. Secondly, there is the challenge of pedagogic content knowledge, the transformation of conceptual knowledge into knowledge-in-practice. Both Le Clercq (2014) and Nathanson (2014) point to the challenges in South African schools of applying and sustaining effective teaching methodologies, both for pre-service and in-service teachers. Clearly our teachers have not been taught the relevant reading concepts and methodologies during their teacher training. Sailors (2008: 647) states that the development of teachers should also focus "on the professional development of comprehension instruction and classroom teachers".

Irrespective of the debates around theories of change in the educational context, it is strongly recommended that teachers be made aware of and given training in frameworks that specifically target explicit comprehension instruction and modeling. Various comprehension instruction frameworks which incorporate specific guidance about reading comprehension instruction have been developed over the past years, for example Palincsar and Brown's (1984) Reciprocal Teaching, Concept-oriented Reading Instruction (Guthrie, 2003; Guthrie, Anderson, Alao \& Rinehart, 1999), Transactional Strategy Instruction (Pressley, 1998), Hedgcock and Ferris' (2009) take on intensive reading, and the Four-pronged comprehension strategy framework developed by McNamara, Ozuru, Best and O'Reilly (2007), to name a few. More locally, Klapwijk (2015b) developed a framework for reading comprehension instruction for South African teaching circumstances and with the specific aim of providing structure to teachers. In-service teachers, while not as captive an audience as teacher trainees, can benefit from training in and follow-up support with the explicit structure and guidelines provided through instructional frameworks for comprehension such as these. Moats (1999: 14) argues that "without instruction and practice, teachers are unlikely to develop the questioning techniques and discussion strategies that promote thoughtful reading by groups of children".

Reading comprehension competencies can transfer across languages and do not have to be learned anew in each language. For example, learning to make predictions, to attend to visual or linguistic clues in a text, identifying setting, main characters, problem and resolution events in stories in one particular language can readily be utilised when reading texts in another language. This is the basis of Cummins' interdependence hypothesis. In the Mudzielwana et al. study (2012), the Grade 3 teachers complained that guidelines for teaching reading comprehension were only available in English and not in Venda. This suggests both a lack of content knowledge with regard to reading (the assumption that reading comprehension is somehow different in every language) and a lack of curriculum knowledge. CAPS documents are available in all official languages. Maybe these documents were not available in Venda at the time that the study was conducted. However, there is also the challenge of getting teachers to actually read the curriculum documents that are available. In terms of pre-service teachers, teacher-training institutions have a captive audience and have the ability to effect change 'from the inside out' by equipping student teachers with the skills required to tackle the South African teaching environment, instead of trying to work 
'from the outside in' through yet another well-intended but short-lived 'development programme', which are generally implemented without the proper post-implementation teacher support. However, Nel (2011: 53) warns that universities have underestimated the demands of competent literacy instruction and assessment, and calls for a "rigorous, researchbased curriculum and opportunities to practice a range of predefined skills and knowledge in reading comprehension assessment". Klapwijk $(2011 ; 2015 \mathrm{~b})$ recommends adding explicit reading comprehension instruction in teacher-training courses, and also that a research component be added to pre-service, in-service and professional development courses. Although the need for improved literacy skills has been noted for decades, the focus on evidence-based practices in literacy is relatively recent. Yet, while research about improving literacy is at an all-time high, the results of such research often do not reach in-service teachers, and neither do they seem to be disseminated to pre-service teachers in a sustainable manner. A research module could make undergraduate students more aware of evidencebased methods; on a long-term level, it could lead to a shift in attitude towards evidencebased methods in schools as these students become employed as teachers. In-service and teacher development courses have the advantage that teachers who have already experienced problems with reading comprehension could be more willing to attempt classroom-based investigations to improve their own practice. In this way, best practice in reading instruction, as identified and proven through research, will take hold in schools from the inside out through our graduate teachers.

In conclusion, it is recommended that future research move in the direction of implementing, monitoring and evaluating well planned and well-designed comprehension intervention programmes in the diverse classroom contexts that characterise South African schools. Such programmes should be differentially tailored for both in-service and pre-service teachers, and be implemented in both HL and FAL so that we can better understand what works or doesn't work, when, how and why, when comprehension is taught explicitly and meaningfully.

Unless our current and future teachers become knowledgeable about literacy, about reading and writing, about how to teach it effectively and meaningfully, and are themselves skilled and well-informed readers who read beyond narrow functional demands, the comprehension levels of South African learners are unlikely to change significantly as we move deeper into the $21^{\text {st }}$ century.

\section{Acknowledgements}

Sincere thanks and appreciation to Dr Oleyume Stephens for assistance with the capturing of questionnaire data on SPSS, and to Mrs Lenore van den Berg for assistance with the distribution of questionnaires.

\section{REFERENCES}

ALEXANDER, N. 2006. The experience of mother-tongue based education in post-colonial Africa, with special reference to South Africa. Input memo prepared for the Language Colloquium, National Department of Education, Cullinan Hotel, Cape Town, 31 July 2006.

BORG, S. 2003. Teacher cognition in language teaching: A review of research on what language teachers think, know, believe, and do. Language Teaching 36: 81-109. 
CENTRE FOR DEVELOPMENT AND ENTERPRISE (CDE). 2015. Is South Africa training enough teachers? CDE Report, March 2015, Johannesburg.

DEPARTMENT OF BASIC EDUCATION. 2014. Report on the Annual National Assessments of 2014: Grades 1-6 \& 9. Pretoria: Government Printer.

DREYER, C \& C NEL. 2003. Teaching reading strategies and reading comprehension within a technology-enhanced learning environment. System, 31: 349-365.

FLEISCH, B. 2008. Primary education in crisis: why South African school children underachieve in reading and mathematics, Cape Town: Juta \& Co.

GAINS, P. 2010. Learning about literacy: Teachers' conceptualisations and enactments of early literacy pedagogy in South African Grade One classrooms. Unpublished doctoral thesis, Johannesburg, University of the Witwatersrand.

GUTHRIE, JT. 2003. Concept Oriented Reading Instruction: Practices of teaching reading for understanding. In AP Sweet \& C Snow (eds). Rethinking reading comprehension. New York: The Guilford Press.

GUTHRIE JT, E ANDERSON, S ALAO \& J RINEHART. 1999. Influences of Conceptoriented Reading Instruction on strategy use and conceptual learning from text. Elementary School Journal, 99(4): 343-366.

HEDGCOCK, JS \& DR FERRIS. 2009. Teaching Readers of English: Students, texts, and contexts. New York: Routledge.

HILL, A. 2003. Themes in current education discourse that impact on teacher education. Journal of Education 31: 93-110.

HOWIE, SJ, E VENTER, S VAN STADEN, L ZIMMERMAN, C LONG, \& V SCHERMAN. 2008, Progress in International Reading Literacy Study 2006, Summary report. South African children's reading literacy achievement. Centre for Evaluation and Assessment, University of Pretoria.

HOWIE S, S VAN STADEN, M TSHELE, C DOWSE \& L ZIMMERMAN. 2012. PIRLS 2011: South African children's reading literacy achievement Summary Report. Pretoria: University of Pretoria.

INTERNATIONAL READING ASSOCIATION (IRA). 2007. Teaching Reading well. A synthesis of the International Reading Association's research on teacher preparation for reading instruction. Newark, DE: International Reading Association. Available at http://www.reading.org

IRVINE-NIAKARIS, C \& R KIELY. 2015. Reading comprehension in test preparation classes: an analysis of teachers' pedagogical content knowledge in TESOL. TESOL Quarterly 49(2): 369-392.

KLAPWIJK, NM. 2011. Reading strategy instruction in Grades 4-6: Towards a framework for implementation. Unpublished $\mathrm{PhD}$ dissertation: Stellenbosch University.

KLAPWIJK, NM. 2015a. Changing student teachers' views of comprehension instruction through the use of a comprehension instruction framework. Journal for Language Teaching 49(1): 81-103. http://dx.doi.org/10.4314/jlt.v49i1.4

KLAPWIJK, NM. 2015b. $\mathrm{EMC}^{2}=$ Comprehension: A framework for reading comprehension instruction. South African Journal of Education 35(1):1-10. http://dx.doi.org/10.15700/201503062348

LE CLERCQ, F. 2014. Improving teachers' practice in poorly performing primary schools: The trial of the GPLMS intervention in Gauteng. Education as Change 14: 1-16.

MCNAMARA, DS. (ed). 2007. Reading comprehension strategies: Theories, interventions and technologies. Mahwah, NJ: Lawrence Erlbaum Associates.

MCNAMARA, DS, Y OZURU, R BEST \& T O'REILLY. 2007. The 4-pronged comprehension strategy framework. In DS McNamara (ed). Reading comprehension 
strategies: Theories, interventions and technologies. Mahwah, NJ: Lawrence Erlbaum Associates.

MOATS, LC. 1999. Teaching reading is rocket science. Washington, DC: American Federation of Teachers.

MUDZIELWANA, NP, I JOUBERT, NC PHATUDI \& CG HARTELL. 2012. Teaching reading comprehension to Grade 3 Tshivenda-speaking learners. Journal of Educational Studies 11(1): 67-84.

MURRIS, K. 2014. Philosophy with children as part of the solution to the early literacy education crisis in South Africa. European Early Childhood Education Research Journal 1-16.

NATHANSON, RR. 2014. A professional development school model for the development of literacy teachers. Per Linguam 30(1): 127-144.

NEEDU (National Education Evaluation and Development Unit). 2013. The state of literacy teaching and learning in the Foundation Phase. Pretoria: National Report 2012.

NEL, C. 2011. Classroom assessment of reading comprehension: How are preservice Foundation Phase teachers being prepared? Per Linguam 27(2): 40-63.

O'SULLIVAN, O \& S MCGONIGLE. 2010. Transforming readers: teachers and children in the Centre for Literacy in Primary Education Power of Reading project. Literacy 44(2): 51-59.

PALINCSAR, AS \& AL BROWN. 1984. Reciprocal teaching of comprehension-fostering and comprehension-monitoring activities. Cognition and Instruction 1(2): 117-175.

PRESSLEY, M. 1998. Comprehension Strategies Instruction. In J Osborn \& F Lehr (eds). Literacy for All: Issues in teaching and learning. New York: The Guilford Press.

PRETORIUS, EJ. 2012. Butterfly effects in reading? The relationship between decoding and comprehension in Grade 6 high poverty schools. Journal for Language Teaching 46(2): 74-95.

PRETORIUS, EJ. 2015. Failure to launch: Matching language policy with literacy accomplishment in South African schools. International Journal for the Sociology of Language 234: 47-76.

PRETORIUS, EJ \& JJ KNOETZE. 2012. The teachers' book club: Broadening teachers' knowledge and building self confidence. Musaion 31(1): 27- 46.

PRETORIUS, EJ \& MMK LEPHALALA. 2011. Reading comprehension in high poverty schools: How should it be taught and how well does it work? Per Linguam 27(2): 124.

PRETORIUS, EJ. \& MP MACHET. 2004. The socio-educational context of literacy accomplishment in disadvantaged schools: Lessons for reading in the early primary school years. Journal for Language Teaching 38(1): 45-62.

PRINSLOO, CH, E RAMANI, M JOSEPH, S ROGERS, A MASHATOLE, M LAFON \& V WEBB. 2015. An inter-province study of language and literacy paradigms and practices in Foundation Phase classrooms in Limpopo and Gauteng. Pretoria: Human Sciences Research Council.

RIMENSBERGER, N. 2014. Reading is very important, but ...: Taking stock of South African student teachers' reading habits. Reading \& Writing 5(1), Art. \#50, 9 pages.

SAILORS, M. 2008. Improving comprehension instruction through quality professional development. In Israel, S.E. \& Duffy, G.G. (eds.) Handbook of Research on Reading Comprehension. New York: Routledge.

SNOW, CE. 2014. Standards in education and training: The challenge. Perspectives in Education 32(1): 11-20. 
SOUTHERN AND EASTERN AFRICA CONSORTIUM FOR MONITORING EDUCATIONAL QUALITY. 2010. SACMEQ III project results: Pupil achievement levels in reading and Mathematics. (Working document no. 1).

TAYLOR, N. 2014. Thinking, language and learning in Initial Teacher Education. Presentation to the seminar Academic depth and rigour in ITE, 30-31 October, Johannesburg: University of the Witwatersrand.

TAYLOR, N \& S TAYLOR. 2013. Teacher knowledge and professional habitus. In N Taylor, S van der Berg \& T Mabogoane (eds.) Creating effective schools. Cape Town: Pearson Education, pp. 201-232.

TAYLOR, N, S VAN DER BERG \& T MABOGOANE. 2013. Context, theory, design. In N Taylor, S van der Berg \& T Mabogoane (eds.) Creating effective schools. Cape Town: Pearson Education, pp. 1-30.

VAN ROOY, B \& EJ PRETORIUS. 2013. Is reading in an agglutinating language different from an analytic language? An analysis of Zulu and English reading based on eye movements. Southern African Linguistics and Applied Language Studies 31(3): 281387.

VAN STADEN, A. 2011. Putting reading first: Positive effects of direct instruction and scaffolding for ESL learners struggling with reading. Perspectives in Education 29(4): $10-21$.

VAN STADEN, S \& S HOWIE. 2010. South African teacher profiles and emerging teacher factors: a picture painted by PIRLS 2006. Reading and Writing 1(1): 47-60.

VERBEEK, DC. 2010. Teaching reading for meaning? A case study of the initial teaching of reading in a mainstream South African school. Unpublished doctoral thesis, Pietermaritzburg: University of KwaZulu-Natal.

WESTERN CAPE EDUCATION DEPARTMENT. 2006. WCED Literacy and Numeracy Strategy 2006 - 2016. Provincial Government Printer.

ZIMMERMAN, L. 2014. Lessons learnt: Observation of Grade 4 reading comprehension teaching in South African schools across the Progress in International Reading Literacy Study (PIRLS) 2006 achievement spectrum. Reading and Writing 5(1), Art. \#48, 9 pages.

ZIMMERMAN, L \& B SMIT. 2014. Profiling classroom reading comprehension development practices from the PIRLS 2006 in South Africa. South African Journal of Education 34(3): 1-9.

\section{BIOGRAPHICAL NOTES}

Elizabeth Pretorius is a professor in the Department of Linguistics \& Modern Languages at the University of South Africa (UNISA). Her research interests include reading, second language learning and teaching, and the development of vocabulary and academic discourse.

Nanda Klapwijk is a senior lecturer in Applied Linguistics in the Department of Linguistics \& Modern Languages at the University of South Africa (UNISA). Her research interests include reading comprehension instruction, multilingual learning and teaching and technology-based learning. 